\title{
Improving Students' Speaking Skill Through Task Based Language Teaching At Mandalika University Of Education
}

\author{
${ }^{1}$ Sugianto, ${ }^{2}$ Kamarudin ${ }^{3}$ Ahmad Hanan \\ ${ }^{1}$ English Lecturer, Faculty of Culture Management And Business, Mandalika University Of \\ Education, Indonesia \\ Co. Author Email: sugianto@ikipmataram.ac.id
}

\begin{abstract}
The article was written to show how the task based language teaching as a language teaching method can improve students' speaking skill at Mandalika University Of Education. The research was conducted by involving the first semester students of english department Mandalika University of education. The type of the research was classroom action research in which task based language teaching was a method adopted to improves the students' speaking skill. Collecting the research data, the researcher used two kinds of research instruments. Speaking tests were used to measure the improvement on students' speaking skill, meanwhile observation was conducted to define how the task based language teaching improves the students" speaking skill. The research was concluded to has some significant improvements on students' speaking skill proved by deviation scores gained between first cycle and second cycles of the research in which the task cycles, interesting topics of discussion, and activities through the task based language teaching method were considered as factors which significantly affected students' speaking skill improvement.
\end{abstract}

Keywords: Task Based Language Teaching, Speaking Skill

\section{INTRODUCTION}

Nowadays, mastering one particular language skill, English in particular is considered as a prestige achievement. Reasonably, people who master English language, especially speaking skill are seen to be easier in getting all successes. For instance like english being used as a way to communicate in sense of easily building connection with other people who come from different culture, language, and country.

All arround the globe, the expansion of science and technology in the world is seemingly enormous and unpredictable. It, then, leads continually to the growth of English as an international language. As an international language, English is used and learned by most people in all parts of the world. It means that English has focal roles in every country, particularly in the development of science and technology.

Harmer (2001:65) said that English nowadays has become a lingua franca, a language which is internationally used by people with different first language background. English is the most widely spoken language worldwide when combining native and non-native speakers. English is estimated by including second language speakers vary greatly, from 470 million to more than 1 billion. The current data said that non-native speakers as of 2003 outnumbered native speakers by a ratio of three to one. Those reasons serve English as an important skill that everyone is required to possess.

In Indonesia, english has been taught in whole levels of formal education such as Elementary, Junior, and Senior High School. The teaching of english involves the foru skills of language, listening, speaking, reading, and writing. Among those four language skill, speaking skill is assumed tobe the most demanded skill (Bailey and Savage, in Murcia 2001). This is due to the fact that most learners often evaluate their success in language learning as well as the effectiveness of their English course on the basis of how much they feel they have improved in their speaking proficiency (Richards, 2008).

However, teaching and learning speaking as second or foreign language are unavoidable from several challenges and 
intricacies since it deals with the following a number of features. First, fluent speech contains reduced forms such as contractions, vowel reduction, and elision, so that learners who are not exposed to or who do not get sufficient practice with reduced speech retain their rather formal-sounding full forms. Second, acquire the stress, rhythm, and intonation of English (Brown, 1994 in Lazarton, in Murcia, 2001). Third, for being able to communicate in the context of sociocultural activities.

The students should have communicative competence that comprises four dimensions encompassing grammatical competence which includes rules of phonology, orthography, vocabulary, word formation, and sentence formation; sociolinguistic competence refers to rules for the expression and understanding social meanings and grammatical forms in different contexts. In addition, speaking skill is not easy since it is almost always accomplished via interaction with at least one other speaker. (Lazarton, 2001 cited in Celce-Murcia, 2001).

To solve above speaking problems, task based language teaching was the solution to make the students have a better speaking skill. How it is possible to solve students' speaking problems by using a teaching method, task based language teaching in particular. It was beacuse a teaching method determined the position of students during teaching progress. It is inline with the statement from Scarcella and Oxford in Celce-Murcia (2001) which claim that a method being used in learning may serve providing self-encouragement to tackle a difficult language task-used by students as to enhance their own learning. If the learners are happy with the applied teaching method, were they active in participating themselves at L2 activities.

In addition, the task based language teaching can be used by the teacher to make learners continuously communicative and interactive within the spoken learning processes. As Cole (2008:34) states that providing effective teaching method in accomplishing students' educational needs is teachers' role, whose general purpose is to communicate using the language being learnt.
For those reason, the researcher then constructed the idea of conducting a study on the use of task based language teaching to improve students' speaking skill at mandalika university of education.

\section{RESEARCH METHOD}

The study belongs to classroom action research. It is a media of change and an improvement of a study (Cohen et al, 2007). Kemmis and McTaggart (1992: 21-2) stated that action research is more systematic and collaborative in collecting evidence on which to base rigorous group reflection. It involves problem-posing, not just problem-solving. It does not start from a view of 'problems' as pathologies. It is motivated by a quest to improve and understand the world by changing it and learning how to improve it from the effects of the changes made. It is a research by particular people on their own work, to help them improve what they do, including how they work with and for others.

Action research is a study to understand, evaluate, change, and improve educational practice. It combines a substantive act with a research procedure, it is action disciplined by enquiry, a personal attempt at understanding while engaged in a process of improvement and reform' Bassey (1998: 93) Hopkins (2002: 41).

The study was conducted to the first semester of english department at Mandalika University Of Education in the school year 2019/2020. It was done from February to June 2020. It was conducted through two cycles. Each cycle consisted of four steps; they were planning, action, observation and reflection. The aim of this point was observing the students' improvement in speaking by using Task-based language teaching approach.

Test was used to asses and examine the students' speaking skill. It was given in each cycle to find out the improvement of the students' speaking skill and effectiveness of using Task-Based language teaching method to improve the students' speaking skill. Meanwhile, observation sheet used to collect data about the students' participation in teaching learning process in speaking and implementing Task-Based Approach. 


\section{FINDING AND DISCUSSION \\ Research Finding}

The research finding is all about the data to answer the research question that says "How does the Task Based Language Teaching improves students' Speaking Skill at the first semester students of Mandalika University Of Education in the school year 2019/2020?" answering this research question, the researcher conducted two cycles of data collecting in which at the first cycle the was not found a significant improvement on students' speaking skill which then mean to be continued to conduct the second cycle. This research was conducted during five months around February to June 2020. Seven times of meeting at cycles one and seven times of the meeting at the second cycle.

The research data were collected through an in depth observation which then reinforced by the result of speaking test of students speaking skill. The first test was given to the students on February 5th 2020 at 11:55-12:40 am. The test examined students' speaking skill by involving the speaking indicators, fluency, accuracy, patterning, language expression, and words choice. The research subjects were given around fifteen minutes to accomplish the speaking test. The test was aimed to know the students' skill in speaking before implementing the task based language teaching.

Based on the result of speaking test, the researcher then analyzed the weaknesses of students' speaking skill as the main data support to implement the task based language teaching to improve those weaknesses. The advantages of using this task based language teaching were fully hoped overcome students' speaking skill problems.

Preliminary test result shows that the mean score gained was 49.4 in which this mean score was away below the passing grade defined 67 . There were nine students or $27 \%$ of 33 students who obtained scores above the passing grade which means the rest 24 students failed and obtained scores below the passing grade. Based on this finding, it is then concluded to continue the next cycle.

The next cycle held the teaching of speaking through a systematic planning which can be described through the following activities:

At first, the researcher and collaborator decided the topic that would be delivered to the students by means of task based language teaching which is then followed by discussing media and material preparation. These activities are involved in the planning section of the research.

The next phase is implementing, things that get done at this phase are the use of task based language teaching implementation to teach English speaking. During the teaching progress, the researcher collaborates with the English teacher in presenting the teaching materials. The teaching is smoothly done through the task based language teaching for eight meetings.

By the end of second cycle of the classroom action research, the researcher gave the students speaking test to measure any improvement made after the implementation of task based language teaching method. Whereas the researcher obtained the result of speaking test as follows: the mean score of the students after conducting the second cycle was 72 which means arisen from the first speaking test result and surely passed the passing grade 67.

The whole research subject was 34 students in which 28 of them were completely passed the passing grade with only six students got failed and obtained the scores below the passing grade. From this result, it could be seen there was an improvement of students' score after using task based language teaching in teaching speaking.

These research finding shows how task based language teaching can really improve students' speaking. The improvement on students' speaking result can be seen through the comparison between first test held in which the mean score was 22.6 and the percentage of students' failed was 54\%. Conversely, after having two cycles of the action research, the students' mean score was highly increased into 72 which means above the level of passing grade. The successful percentage was $81 \%$ where 28 students successfully passed the passing grade. Thus, teaching English speaking skill through task 
based language teaching gave satisfactory results on the improvement of students' speaking skill.

In addition, during the teaching and learning process, it was found that the students were enjoy the learning process, they enthusiast in finished their task, they gave an answered for the question given by teacher, those meant the students actively participate in the class during teaching and learning process. These evidences highly recommend the task based language teaching to be used as the teaching strategy in improving students' speaking skill.

\section{Speaking achievement}

The following table shows the major speaking skills improvement gained by the students on using English task based language teaching as a method of teaching.

\begin{tabular}{lllll}
\hline $\begin{array}{l}\text { Speaking } \\
\text { skill }\end{array}$ & $\begin{array}{l}\text { First } \\
\text { cycle }\end{array}$ & $\begin{array}{l}\text { Second } \\
\text { cycle }\end{array}$ & Deviation & Percentage \\
\hline $\begin{array}{l}\text { Mean } \\
\text { score }\end{array}$ & 49.4 & 72 & 22.6 & $27 \%-81 \%$ \\
\hline
\end{tabular}

Table 1. Students' Speaking Skill Improvement

The reasons why the researcher came up with the conclusion that there was an improvement of students' speaking skill after having two cycles of the task based language teaching method in teaching speaking is that the six speaking skills indicators were fulfilled satisfactorily. The students had a good grammar when they speak. It was seen when the students put word order such like subject, object, and verb accordingly. The students pronounced every single sentence appropriately into a meaningful sentence. The used vocabulary choice appropriately and considering the discourse features in it. They completed the tasks given enthusiastically and did it on time. Those indicators are a complete signs to approve that there were some significant improvements on students speaking skill.

\section{Discussion}

Based on the result of the speaking tests, which shows significant improvement on students' speaking skill. The researcher then analyzed some factors that influenced those improvements. These factors were gained through the result of observation distributed along with the speaking test.
Based on the result of observation, it was known that the used of task based language teaching as a method of teaching speaking enforced the students in a positive way to have a better speaking skills which then lead the students found it easier at the next phases of doing speaking. Once it felt hard, the next steps they used to and found it easy.

The next factors that effected the students' speaking skill improvement was "task cycle" the result of observation shows that task cycle gave a drilling points to the students to get used to. The task seems to be fun at the time it has become habitual. These kind of activities made the students getting more and more competent in English speaking skill.

The next factor that made the task based language teaching successfully increased students speaking skill was the interesting topics of discussion given. The topics of discussion like "first impression on lecturer" and "take a vacation" are the examples of the topics discussion which brought the students into real life and triggered the students to say what they have in mind about the first time meeting the lecturer as well as atheistically telling their experiences on a trip.

Those factors plays role in teaching speaking skill through task based language teaching. Surely, the indicators involved in assessing speaking skills already been determined. Those indicators were taken from Brown (2003) said there are six indicators of speaking skills those are pronunciation, fluency, grammar, vocabulary, discourse features, and task accomplishment. Following these speaking skill indicators, the researcher assessed the students' speaking through a valid speaking test.

The used of task based language teaching had help the students to improve the English pronunciation which then impacts students' fluency in speaking. Once they pronounced the words properly, at the same time they had also improve their fluency. These improvements surely achieved through the use of task based language teaching.

Grammar and vocabulary are the two indicators as well as pronunciation and fluency determined speaking skill. Through 
this task based language teaching, students' vocabulary and grammar mastery had also been improved. The data shows that students could use over 500 different words in their speaking task. Arranging these 500 different words need grammar skill, and of course it was also been improved.

In accomplishing the speaking task, the students are required to perform a speaking practice. The discourse features like expression, mimic, body languages were involved in this speaking performance. With such kind of activities, surely improves students' skill in using various types of discourse features.

\section{CONCLUSION AND SUGGESTION \\ Conclusion}

Concluding the result of study, it was surely informed that the research was focused on how does the task based language teaching as a type of teaching method works to improve students' speaking skill at the Mandalika University of Education in academic year 2019/2020. For the sake of that research focus, the two research instruments, speaking test and observation sheet were used to collect the data. In a brief conclusion here are some findings that were found through the research:

1. Task based language teaching can improves students' speaking skill at Mandalika University Of Education in the school year 2019/2020. The conclusion is strengthened by the result of speaking test deviation at the preliminary, first cycle, and second cycles of the action research.

2. Task cycles, interesting topics of discussion, and Task based language teaching itself, were some factors affect students' speaking skill improvement. The researcher came up with these conclusions based on the result of data collected through the observation sheet questioning of some factors that play important roles in improving students' speaking skill.

\section{SUGGESTION}

A perfect research study is always a hope for every researcher who conducts a study by hearth and time. However, limitations is always been there even stated in early part of the study. Considering the result of the study, as well as the research finding which shows some significant improvements on students' speaking skill by means of task based language teaching, the researcher suggest the following suggestions for the future researches which have relevant issues.

1. This research is limited on finding how does the task based language teaching improves students' speaking skill. Thus, the future researches could examines a further issues dealing with task based language teaching, including the language skill being tested. Listening, reading, as well as writing skill also potentially improved thorough this task based language teaching method, give it try.

2. Using various models to support the task based language teaching as a method, potentially helps the future researchers to gain a more satisfactory research result and finding. These models could enrich the students' activities and creativities that lead into new bright findings on the use of task based language teaching.

3. The future researches are suggested to use task based language teaching in a broader scope to enrich and expand the researches result and finding.

\section{REFERENCES}

Bailey, K. M. (2005). Practical English Language Teaching: Speaking. New York: McGraw-Hill.

Brown, H. D. (2001). Teaching by Principles: An Interactive Approach to Language Pedagogy. England. Longman

Brown, H. D. (2004) Language assessment: Principles and classroom practices. New york: Pearson Education.

Burns, Anne (2010) Doing Action Research In English Language Teaching Guide For Practitioner. New York: Taylor and Francis Group.

Celce-Murcia, Marianne. (2001). Teaching English as a Second or Foreign Language. Boston: Heinle and Heinle, Inc. 
David Nunan. (2003) Practical English Language Teaching. New York : Mc Graw Hill

Jack Richard. (2008). Teaching Listening and Speaking: From Theory to Practice. USA: Cambrige University Press.

Jeremy Harmer. (2001) The Practice Of English Language Teaching. England. Longman.

Jeremy Harmer. (2007). The Practice of English Language Teaching (Fourth Edition). London: Pearson Education Limited.

Kayi (2006) Teaching Speaking: Activities to Promote Speaking in a Second Language. Nevada. University of Nevada.

Michaela Sepesiova (2015) Development Of Speaking Skill In English Language Classes. Slovakia. University of Presov in Presov.

Solcova, P. (2011). Teaching Speaking Skills. Thesis of Faculty of Arts of Masaryk University: Unpublished.

Sugiyono. 2014. Metode Penelitian Pendidikan. Bandung: ALFABETA,CV.

Thornbury (2005) How to Teach Speaking. Cambridge University Press.

Yule, G. (2006) The Study of Language: Third Edition. Cambridge University Press. 